\title{
Response of 'Bignay' [Antidesma bunius (Linn.) Spreng] to cutting origins, IBA and BioGroe treatments
}

\author{
Edgar V Benabise ${ }^{1^{*}}$, Jonalyn J Quinan ${ }^{2} \&$ Joel G Carig ${ }^{2}$ \\ ${ }^{1}$ College of Agriculture, Forestry and Engineering, Quirino State University, Andres Bonifacio, Diffun, Quirino 3401, Philippines \\ ${ }^{2}$ Department of Forestry, Quirino State University, Andres Bonifacio, Diffun, Quirino 3401, Philippines \\ *Email: benabiseedgar@gmail.com
}

\section{ARTICLE HISTORY}

Received: 23 December 2020

Accepted: 22 May 2021

Available online: 01 July 2021

KEYWORDS

Bignay

Cutting origin

Plant bio-regulators

Shoot length

Root number

Percent rooting

Percent survival

\section{ABSTRACT}

The response of 'Bignay' [Antidesma bunius (Linn.) Spreng] to the cutting origins and different levels of plant bio-regulators consist of Indole-3-butyric Acid (IBA) and Biogroe treatments were investigated by means of $3 \times 9$ factorial experiment in Completely Randomized Design (CRD) using an automated mist propagator. Two hundred sixteen (216) healthy seedlings containing 9 nodes each were used in the study. Results revealed that cutting origins significantly increased shoot length but have no influence on the root number, percent rooting and percent survival. The cuttings originated from the bottom portion of the stem recorded the longest mean in terms of shoot length $(12.48 \mathrm{~mm})$ including the highest percent survival and percent rooting (82.41\%). Highest mean number of roots were observed on the top cuttings (1.93). Indole-3-butyric Acid (IBA) and Biogroe treatments on cuttings have no effects on the different parameters evaluated. The interaction effect between cutting origins and IBA/ Biogroe treatments significantly increased the percent rooting and percent survival except the shoot length and root number of Bignay cuttings. Overall, the findings inferred that $A$. bunius can be propagated by any cutting origin derived from the main stem of the donor plants tested. Cuttings can effectively be induced to produce roots and survive and can be economically mass propagated even without the application of different concentrations of IBA and BioGroe.

\section{Introduction}

Native trees are very important in the web of life. They are the foundation of our natural ecosystems (1). They provide food and shelter to wildlife much better than introduced tree species. Native trees also adapt naturally to their local surrounding, thus more resilient than introduced species (2). They also retain their natural capacity to form devastation caused by raging weather and from pests and diseases (1).

In recent decades, there was a sharp decline in the population of native trees because of destructive and extractive human activities. Deforestation, replacement by invasive alien species, mono-crop plantations that propagate only commercially popular varieties (3) and the rapid proliferation of exotic plant species (4) are some of the reasons why native trees have been disappearing at a very fast rate. Morever, local people also continuously replacing economically important tree species with "money trees" like Gmelina and Mahogany for profit. As a result, a significant number of native tree species were moved to "endangered" status because of the dwindling population and continuous threat.
The diminishing population and the threat of extinction of native trees justify the need to exert more effort to protect the fast desertion of native fruit and forest tree species in the country. The Ecosystems Research and Development Bureau (ERDB) in the country have already conducted researches in the macro propagation of native tree species to restore their status but concentrated on the Dipterocarp tree and well known native tree species but not on lesser known fruit and forest tree species. Hence, the researchers proposed the research project, "Development of Clonal Propagation Protocols for Native Forest and Fruit-Bearing Tree Species of Quirino and Nearby Provinces" funded by the The Department of Science and Technology- Philippine Council for Agriculture, Aquatic and Natural Resources Research and Development ((DOSTPCAARRD). One of the fifteen identified fruit tree species included in the study is 'Bignay'.

Antidesma bunius (Linn.) Spreng ('Bignay') is an endemic tree species of Euphorbiaceae family. It is a dioecious tree, usually reaches a height of about 10 meters. The tree grows well in the primary or secondary montane rain forest reaching about 1800

(c) Benabise et al (2021). This is an open-access article distributed under the terms of the Creative Commons Attribution License, which permits unrestricted use, distribution and reproduction in any medium, provided the original author and source are credited (https://creativecommons.org/licenses/by/4.0/) 
meters altitude. They grow well in alluvial flats, clayey soils, peaty soils, volcanic soils, podzols and limestone type of soils (5). The edible fruit develops in clusters like grapes and its size reaches $8 \mathrm{~mm}$ long containing one seed per fruit. 'Bignay' fruit juice contains health-stimulating chemical compounds such as phenolic, anthocyanin, ascorbic acid and flavonoid that can be a natural source of antioxidants (6). Also, the entire plant is used as an antidysenteric, antioxidative, anticancer, antidiabetic and gives sudorific effects that increase its medicinal significance. Likewise, the leaves are sudorific and employed in treating snakebite in Asia (7).

'Bignay' seeds can be sown one month after ripening under the shade without pre-treatment (5). Its seeds germination rate ranges from $3 \%$ to $30 \%$ which will take 30 to 60 days after sowing. The low viability rate of 'bignay' seed makes the supply of quality seeds inadequate which posed a major problem for massive planting and restoration. The present status of bignay needs immediate action to conserve, multiply and prevent the species from being endangered.

In the absence of quality seeds, the use of other plant parts such as stem as planting propagule is a possible alternative. Vegetative propagation through stem cutting has been acknowledged as an effective technique of rapid propagation of exact replica, trueto-type of the needed tree species for commercial plantation with fast reproductive gains (8) and germplasm preservation of vital tree species (9). As affirmed in a study (10), due to the reduced time needed for cuttings of excellent quality trees to produce roots and survive, this method of propagation is a rapid and very essential nursery management technique that accelerates planting stock production.

With the rigorous management of forest areas and the proliferation of fast growing exotics, including the genetic improvement of forest tree species, it is vital to develop quick and cost effective methods of producing top quality planting stock. Vegetative propagation technique through stem cutting of forest trees is very promising for the reproduction of clones and for fast increase of planting stocks. Clones provide the advantages of genetic uniformity and the rapid multiplication of superior trees for seed orchards and plantations.

Successful vegetative propagation through stem cuttings was successfully undertaken through the application of plant bio-regulators. As a result, ERDB reported to have successfully propagated seven species of dipterocarp by cuttings through a non-mist propagation system using different plant bioregulators with high rooting performances (11). Bioregulators affect the fundamental processes of plant growth and development. Indole-3-butyric acid (IBA), Indole-3-acetic acid (IAA) and Naphthalene acetic acid (NAA) are plant bio-regulators belonging to the auxin group that play an important role in root initiation (12). The most relevant role of auxins in plant propagation is that they stimulate root initiation on stem and leaf cuttings and the development of branch roots (13). This function of auxin is essential for the propagation of cuttings in many plant species used in horticultural and in forestry industries. Usually, Indole-3-butyric acid (IBA) is found to be the most effective root promoting auxin (14) and least toxic for plant tissues (15). IBA has important functions in several phases of root development that include adventitious root formation (16). IBA also enhances rooting since it translocates poorly and is retained near the site of application (17).

BiGroe, on the other hand, is made up of solidbased microbial plant growth promoter comprising of Plant Growth-Promoting Bacteria (PGPB). PGPB are associated with bacteria that affect root growth. These bacteria synthesize plant hormones provide nutrients in insoluble form. PGPB also shield plant surface against pathogenic microbes that attack through direct competitive effects and creation of antimicrobial compounds. As pointed out in a study (18), plant hormone produced by soil microorganisms are tangled in plant growth promotion and development. This is due to the creation of plant growth regulators like gibberellins, auxins and cytokinins. BioGroe trials were successfully conducted to different crops with an increased yield of $8 \%$ to $88 \%$ and resulted to a higher income for the farmer. For ornamentals and other cut plants, the cuttings effectively survived at a ratio of 1:10 ratio of BioGroe to water suspension (19). There is no study conducted yet on trees using BioGroe as a root enhancer hence, the result of this test was first-hand information contributing to BioGroe technology.

Thus, the study determined the effect of cutting origins, IBA and BioGroe treatments on the growth and survival of $A$. bunius. It aimed to generate information of the macro-clonal propagation protocol for $A$. bunius that serves as a guide for proper propagation of the species to improve its germplasm, for ex-situ conservation, and for mass propagation for the establishment of a future plantation to adequately supply the raw materials needed by wine producers in the upland communities. Specifically, to find the best cutting origin that will significantly increase the survival and rooting of cuttings and to determine the most effective root promoting hormone and economical dosage best for the propagation through cuttings.

\section{Materials and Methods}

\section{Collection and Maintenance of wildlings along Hedgerows}

Two hundred and sixteen (216) wildlings of 'bignay' about 0.1 to $0.2 \mathrm{~m}$ were earth-balled from the mountainous ranges of Quirino province. These were initially placed in a mist chamber, acclimatized in nursery condition (i.e. Increasing the amount of outdoor exposure one hour each day to gradually acclimate the seedlings to increasing amounts of dappled sun and wind). The seedlings were finally grown in a $200 \mathrm{~m}^{2}$ hedgerows established beside the clonal nursery of the university. These were maintained until they have reached approximately 610 nodes and are at least $0.9 \mathrm{~m}$ in height (Fig. 1).

\section{Preparation of Cuttings}

Two hundred and sixteen (216) healthy stem cuttings 

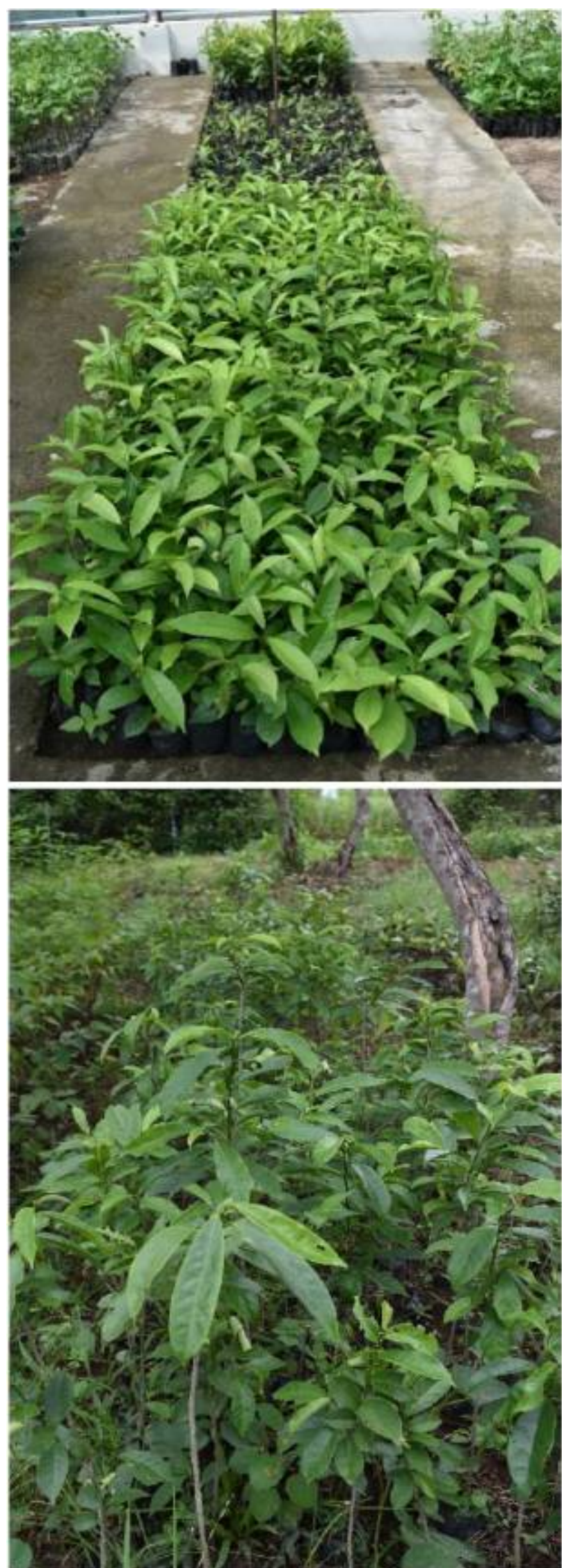

Fig. 1. 'Bignay' seedlings acclimatized in nursery condition and maintained along hedgerows.

containing 9 nodes each were obtained from the seedlings grown along the hedgerows were used in the study. Cuttings were collected early in the morning and leaves were reduced to half their size to minimize transpiration. The cuttings were placed in a basin filled with water to wash off dust and to avoid drying. These were soaked in 5\% Benlate solution, a fungicide for $30 \mathrm{~min}$ to eliminate fungal contamination. The cuttings were divided into three parts: top (1st-3rd nodes), middle (4th-6th nodes) and bottom $\left(7^{\text {th }}-9^{\text {th }}\right.$ nodes $)$. These were bundled into 24 cuttings with the basal part at the same end trimmed and soaked in their specific dosage of rooting hormone treatments (Fig. 2).

\section{Preparation of Rooting Chamber}

The propagation chambers inside the clonal propagation facility are structures provided with elevated rooting beds (rooting chambers) equipped with a programmable mist system. The whole rooting bed had an area of $6 \mathrm{sq} \mathrm{m}$ and was divided into three chambers having dimensions of $1 \mathrm{~m} \times 2 \mathrm{~m}$ each. Each

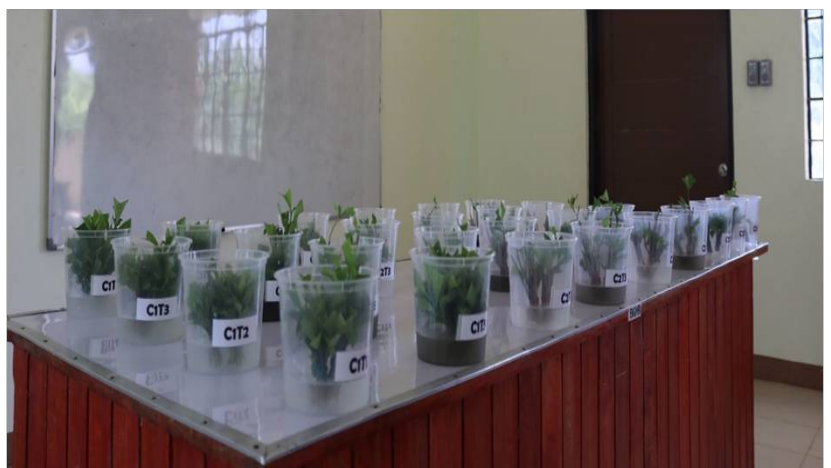

Fig. 2. 'Bignay' cuttings treated with different rooting hormone concentrations.

rooting chamber is sealed tightly with polyethylene plastic no. 8. The chambers were cleaned and washed by a fungicide (i.e. $200 \mathrm{ppm}$ Benlate) solution to minimize possible fungi contamination. The rooting bed was filled with layers of sterilized gravel and sand. The gravel layer as the first layer has a thickness of $5 \mathrm{~cm}$ and the sand layer as the surface layer has a thickness of $20 \mathrm{~cm}$. A net is placed between them to avoid the mixing of the gravel and sand. The planted cuttings were watered using the automatic mist system. This was programmed so that the cuttings were watered in an interval to keep the cuttings moist always.

\section{Preparation of Rooting Media}

Pure river sand collected from Bagabag, Nueva Vizcaya was used as a rooting media for the experiment. The rooting media was sterilized in an improvised autoclave through steam cooking for up to $80^{\circ} \mathrm{C}$ to eliminate all possible microorganisms that could contaminate the cuttings. This was sprayed first with a fungicide solution to eliminate some available fungi in the media. The rooting medium was divided into compartments based on the experimental layout and labels were established for easier planting of the cuttings (Fig. 3).

\section{Preparation of Rooting Hormone}

The rooting hormone IBA was prepared in powder form. Using a digital weighing scale (Merc-2 gms capacity), $1 \mathrm{gm}$ of powdered/solid form of IBA was diluted with enough distilled water and exposed to a water bath at $45^{\circ} \mathrm{C}$. After which, this was vortexed or titrated using the titrator machine. When properly diluted, the rooting hormone was volumed to $1000 \mathrm{ml}$ 

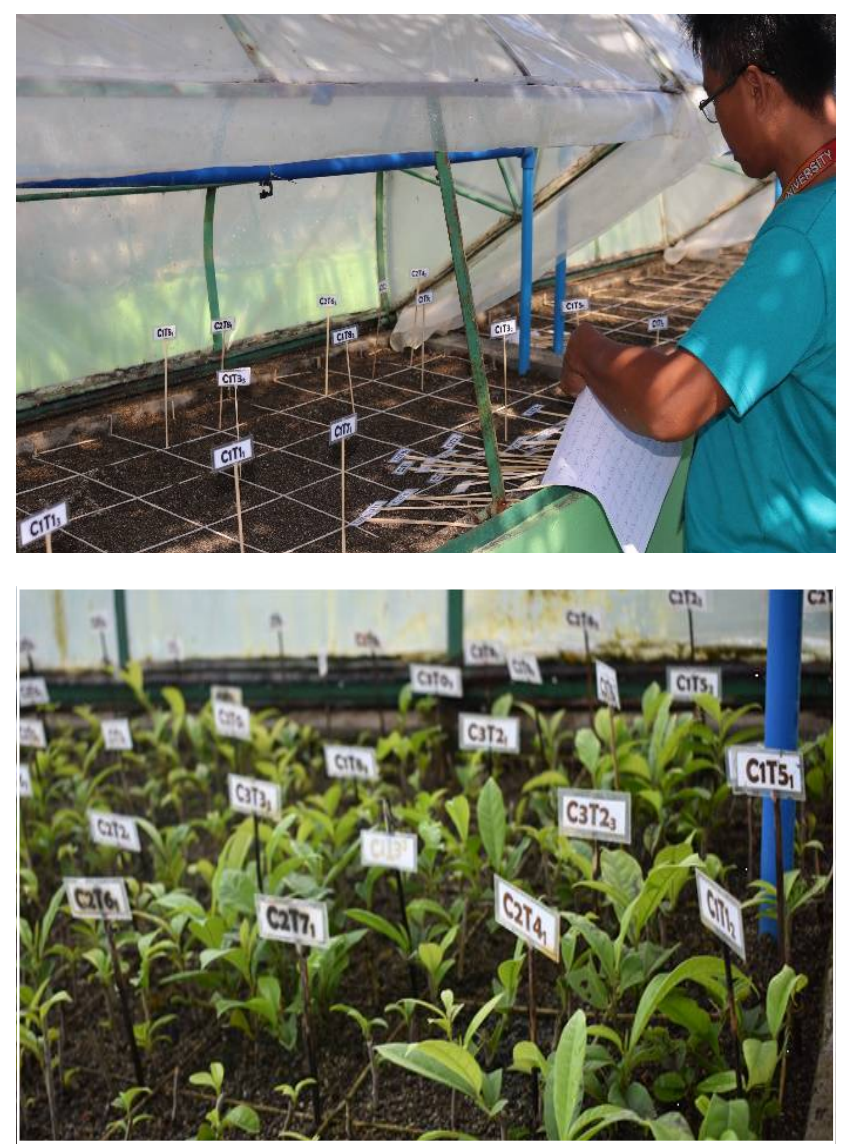

Fig. 3. Rooting media divided into compartment based on experimental layout.

by adding $1 \mathrm{l}$ of distilled water using a volumetric flask producing a stock solution of $1000 \mathrm{ppm}$ concentration (20). Varying concentration of 500 ppm, 1500 ppm and 2000 ppm was prepared from that stock solution of $1000 \mathrm{ppm}$ by serial dilution. The same procedure was used in preparing the different levels of BioGroe treatments.

\section{Parameters Measured}

Assessment of treatment effects was done after 3 months. The following parameters were obtained:

- Mean number of adventitious roots, average shoot length, percent survival and percent rooting.

- The mean number of adventitious roots was calculated by counting the total number of roots emanated from the base of all cuttings per treatment divided by the total cuttings used per treatment.

- The average shoot length was determined by dividing the total length of shoots over the total number of sample cuttings with shoots. Shoot length was measured using a foot rule from the point of origin of the shoots up to the tip of the elongated shoots.

Percent survival was computed by dividing the number of surviving cuttings that produced roots and shoots at the end of the experiment with the total number of stem cuttings planted and then multiplied by 100 .

Percent rooting was determined by dividing the actual number of cuttings that rooted with the total number of cuttings planted and then multiplied by
100. Photos of survived cuttings that produced roots and shoots are shown (Fig. 4).

\section{Experimental Design, Treatments and Statistical Analysis}

The study utilized a 3 x 9 factorial experiment laid out in a factorial Complete Randomized Design (CRD) replicated three times. A two-way Analysis of Variance (ANOVA) was used to determine the significance of the data collected. A comparison of treatment means was done for parameters showing significant differences using the Duncan's Multiple Range Test (DMRT). A statistical package (Statistix 10) was used for the data analysis.

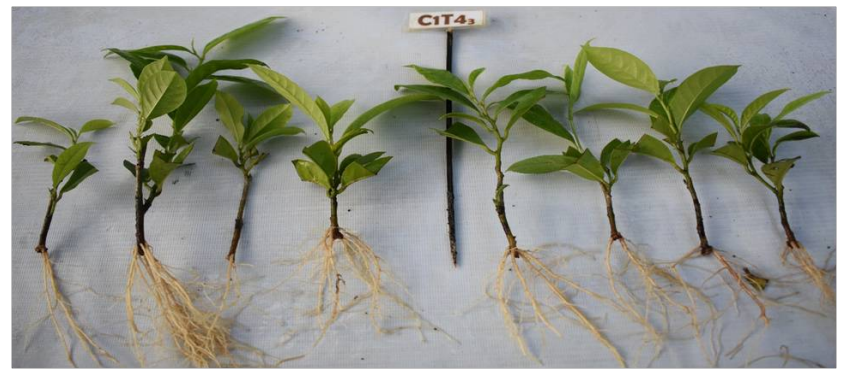

Fig. 4. 'Bignay' cuttings with roots and shoots.

There were two factors used in the study. Factor A composed of three cutting origins. $C_{1}$ were cuttings collected from the topmost part of the seedlings having the $1^{\text {st }}$ three nodes with a pair of healthy leaves. $\mathrm{C}_{2}$ were cuttings collected from the middle portion of the donor plant containing the $4^{\text {th }}$ to $6^{\text {th }}$ nodes with a pair of healthy leaves and $C_{3}$ were cuttings derived from the bottom part of the donor plat containing the $7^{\text {th }}$ to $9^{\text {th }}$ nodes.

Factor B was the hormonal treatments applied to the cuttings. There were 27 treatment combinations used per replication in the study (Table 1).

\section{Results and Discussion}

\section{Percent Survival}

The percent survival of the cuttings as affected by its origin showed no significant difference among each other (Table 2). The highest survival rate was observed in the bottom cuttings $(82.41 \%)$ followed by the top cuttings $(81.48 \%)$ and the lowest was recorded by the middle cuttings ( $72.22 \%)$, however, they do not vary statistically (Table 3 ). The high rate of survival was due to the juvenile state and presence of endogenous auxins in all cutting. As explained in a study (21), juvenile stem cuttings ensured higher photosynthetic activity due to an increase of stomatal conductance which leads to more supply of carbohydrates for root development and subsequent survival of the cuttings.

Among the levels of IBA and BioGroe treatments, the highest percent survival was exhibited by cuttings with 500 ppm IBA (86.11\%) followed by cuttings treated with 500 ppm BioGroe (83.33\%), and the least $(70.83 \%)$ was yielded by the control (Table 4). However, the data showed that the application of IBA and BioGroe have no significant effect on the percent survival of the cuttings. This means that the cuttings can still survive even without the application of IBA or BioGroe. 
The Analysis of Variance (ANOVA) on the percent survival of $A$. bunius cuttings as affected by various levels of IBA and BioGroe revealed no significant difference. This conforms with a research finding conducted in propagating Dillenia suffruticosa (Griff.) Martelli (22). However, the interaction effect of cutting origins and rooting hormone levels showed by the top cuttings ( $81.48 \%$ ) and the least was noted in the middle cuttings $(72.22 \%)$. This coincides with the findings of a study (23) where hardwood cuttings taken from the basal part of the stem recorded the highest rooting percentage $(82.57 \%)$.

Table 3 indicates that using any of the 3 set of cutting will yield a high rooting percentage. It is

Table 1. Treatment Combinations for the experiment

\begin{tabular}{|c|c|c|c|c|c|}
\hline \multicolumn{2}{|c|}{ Top Cuttings (C1) } & \multicolumn{2}{|c|}{ Middle Cuttings (C2) } & \multicolumn{2}{|c|}{ Bottom Cuttings (C3) } \\
\hline C1 T1 & Control (distilled H2O) & C2 T1 & Control (distilled H2O) & C3 T1 & Control (distilled H2O) \\
\hline $\mathrm{C} 1 \mathrm{~T} 2$ & 500 ppm IBA & $\mathrm{C} 2 \mathrm{~T} 2$ & $500 \mathrm{ppm} \mathrm{IBA}$ & C3 T2 & 500 ppm IBA \\
\hline C1 T3 & $1000 \mathrm{ppm}$ IBA & C2 T3 & 1000 ppm IBA & C3 T3 & $1000 \mathrm{ppm}$ IBA \\
\hline $\mathrm{C} 1 \mathrm{~T} 4$ & $1500 \mathrm{ppm} \mathrm{IBA}$ & $\mathrm{C} 2 \mathrm{~T} 4$ & $1500 \mathrm{ppm} \mathrm{IBA}$ & C3 T4 & $1500 \mathrm{ppm} \mathrm{IBA}$ \\
\hline C1 T5 & $2000 \mathrm{ppm} \mathrm{IBA}$ & C2 T5 & $2000 \mathrm{ppm} \mathrm{IBA}$ & C3 T5 & 2000 ppm IBA \\
\hline C1 T6 & 500 ppm BIOGROE & C2 T6 & 500 ppm BIOGROE & C3 T6 & 500 ppm BIOGROE \\
\hline C1 T7 & 1000 ppm BIOGROE & C2 T7 & 1000 ppm BIOGROE & C3 T7 & 1000 ppm BIOGROE \\
\hline C1 T8 & $1500 \mathrm{ppm}$ BIOGROE & $\mathrm{C} 2 \mathrm{~T} 8$ & $1500 \mathrm{ppm}$ BIOGROE & C3 T8 & $1500 \mathrm{ppm}$ BIOGROE \\
\hline C1 T9 & 2000 ppm BIOGROE & C2 T9 & 2000 ppm BIOGROE & C3 T9 & 2000 ppm BIOGROE \\
\hline
\end{tabular}

Table 2. Summary of the Analysis of Variance on percent survival, percent rooting, number of adventitious roots and length of shoots of Bignay (Antidesma bunius)

\begin{tabular}{lccc}
\hline \multicolumn{1}{c}{ Source of Variation } & $\begin{array}{c}\text { Percent (\%) } \\
\text { survival }\end{array}$ & $\begin{array}{c}\text { Percent (\%) rooting } \\
\text { Number of adventitious } \\
\text { roots }\end{array}$ & $\begin{array}{c}\text { Length of shoots } \\
\text { (mm) }\end{array}$ \\
\hline FACTOR A & $3.07 \mathrm{~ns}$ & $3.07 \mathrm{~ns}$ & $0.47 \mathrm{~ns}$ \\
\hline FACTOR B & $0.65 \mathrm{~ns}$ & $0.65 \mathrm{~ns}$ & $1.88 \mathrm{~ns}$ \\
\hline FACTOR A X B & $2.00^{*}$ & $2.00^{*}$ & $1.51 \mathrm{~ns}$ \\
\hline CV (\%) & 21.22 & 21.22 & $2.05^{* *}$ \\
\hline * & $1.54 \mathrm{~ns}$ & 2.59 \\
\hline
\end{tabular}

* significant at 5\% level ; ** significant at $1 \%$ level; ns = not significant

Table 3. Summary of the parameters evaluated as affected by the different cutting origins of Bignay (Antidesma bunius)

\begin{tabular}{|c|c|c|c|c|}
\hline Cutting Origins & Percent (\%) survival & Percent (\%) rooting & $\begin{array}{l}\text { Mean Number of } \\
\text { adventitious roots }\end{array}$ & $\begin{array}{l}\text { Mean Length of shoots } \\
(\mathrm{mm})\end{array}$ \\
\hline Top Cuttings & 81.48 & 81.48 & 1.93 & $8.71^{\mathrm{b}}$ \\
\hline Middle Cuttings & 72.22 & 72.22 & 1.74 & $10.96^{\mathrm{ab}}$ \\
\hline Bottom Cuttings & 82.41 & 82.41 & 1.85 & $12.48^{\mathrm{a}}$ \\
\hline F Computed & $3.07^{\text {ns }}$ & $3.07^{\text {ns }}$ & $0.47^{\mathrm{ns}}$ & $5.50^{* *}$ \\
\hline CV (\%) & 21.22 & 21.22 & 28.59 & 29.21 \\
\hline
\end{tabular}

** significant at $1 \%$ level; ns = not significant

Table 4. Summary of the parameters evaluated as affected by the different rooting hormone treatments of Bignay (Antidesma bunius)

\begin{tabular}{|c|c|c|c|c|}
\hline $\begin{array}{c}\text { Different levels of rooting } \\
\text { hormone treatment }\end{array}$ & $\begin{array}{c}\% \\
\text { Survival }\end{array}$ & $\begin{array}{c}\% \\
\text { Rooting }\end{array}$ & $\begin{array}{c}\text { Mean number } \\
\text { of adventitious roots }\end{array}$ & $\begin{array}{c}\text { Mean length of shoots } \\
(\mathrm{mm})\end{array}$ \\
\hline T1 - Distilled $\mathrm{H}_{2} \mathrm{O}$ & 70.83 & 70.83 & 1.44 & 10.42 \\
\hline T2 - 500 ppm IBA & 86.11 & 86.11 & 1.89 & 8.81 \\
\hline T3 -1000 ppm IBA & 75.00 & 75.00 & 2.00 & 12.52 \\
\hline T4 - 1500 ppm IBA & 80.56 & 80.56 & 1.89 & 11.02 \\
\hline T5 - 2000 ppm IBA & 76.39 & 76.39 & 2.56 & 14.75 \\
\hline T6 - 500 ppm Biogroe & 83.33 & 83.33 & 1.89 & 11.44 \\
\hline T7 -1000 ppm Biogroe & 79.17 & 79.17 & 1.56 & 9.66 \\
\hline T8 - 1500 ppm Biogroe & 77.78 & 77.78 & 1.67 & 9.35 \\
\hline T9 - 2000 ppm Biogroe & 79.17 & 79.17 & 1.67 & 8.49 \\
\hline F computed & $0.65^{\mathrm{ns}}$ & $0.65^{\mathrm{ns}}$ & $1.88^{\mathrm{nS}}$ & $2.03^{\mathrm{ns}}$ \\
\hline CV $(\%)$ & 21.22 & 21.22 & 28.59 & 29.21 \\
\hline
\end{tabular}

ns = not significant

a significant difference at a $5 \%$ level of confidence. This means that the percent survival was different for every treatment combination. DMRT results showed that top cuttings applied with 500 ppm IBA was significantly different from untreated top cuttings, top cuttings treated with 1000 ppm IBA, untreated middle cuttings, middle cuttings with 500 ppm IBA treatment, top cuttings applied with 500 ppm BioGroe and middle cuttings with 2000 ppm BioGroe (Table 5).

\section{Percent Rooting}

Percent rooting of cuttings was not influenced by cutting origins in Bignay. As shown in the Analysis of Variance (ANOVA), it was observed that there is no significant difference among the percent rooting of each cutting origin (Table 2). This implies that the percent rooting of 'bignay' is not dependent on the origin cuttings. The highest rooting percentage $(82.41 \%)$ was obtained by the bottom cuttings followed possible that the age of the ortet where the 3 stem cutting origins were derived contributed to the high rooting of the cuttings. This could be connected to the report that juvenile seedlings as a source of cuttings produce lower rooting inhibitors as compared to older plants (24). This report coincides with the findings that, propagating juvenile leafy stem cuttings of Litsea monopetala (Roxb. ex Baker) Pers. can be a helpful method to increase the rooting percentage (25).

The different concentrations of IBA and BioGroe applied to cuttings revealed that there is no effect on the percent rooting of bignay cuttings (Table 4). The highest rooting percentage was exhibited by cuttings treated with 500 pm IBA (86.11\%) followed by cuttings applied with 500 ppm BioGroe while the lowest was in cuttings treated with control (70.83\%). This implies that bignay is an easy to root species. Easy to root plants respond better to the exogenous 
Table 5. Comparison of means for the interaction effect of cutting origin and rooting hormone levels on percent survival and percent rooting of 'Bignay' (Antidesma bunius)

\begin{tabular}{|c|c|c|}
\hline $\begin{array}{c}\text { Interaction of } \\
\text { Factor A X B }\end{array}$ & Percent Survival (\%) & Percent Rooting (\%) \\
\hline C1T1 & $54.17^{\mathrm{d}}$ & $54.17^{\mathrm{d}}$ \\
\hline $\mathrm{C} 1 \mathrm{~T} 2$ & $100.00^{\mathrm{a}}$ & $100.00^{\mathrm{a}}$ \\
\hline C1 T3 & $58.33^{\text {cd }}$ & $58.33^{\mathrm{cd}}$ \\
\hline C1T4 & $87.50^{\mathrm{abc}}$ & $87.50^{\mathrm{abc}}$ \\
\hline C1T5 & $95.83^{\mathrm{ab}}$ & $95.83^{\mathrm{ab}}$ \\
\hline C1T6 & $83.33^{\mathrm{abcd}}$ & $83.33^{\mathrm{abcd}}$ \\
\hline C1T7 & $70.83^{\text {bcd }}$ & $70.83^{\text {abcd }}$ \\
\hline C1T8 & $91.67^{\mathrm{ab}}$ & $91.67^{\mathrm{ab}}$ \\
\hline C1T9 & $91.67^{\mathrm{ab}}$ & $91.67^{\mathrm{ab}}$ \\
\hline C2T1 & $66.67^{\mathrm{bcd}}$ & $66.67^{\text {bcd }}$ \\
\hline C2T2 & $66.67^{\text {bcd }}$ & $66.67^{\text {bcd }}$ \\
\hline C2T3 & $79.17^{\mathrm{abcd}}$ & $79.17^{\mathrm{abcd}}$ \\
\hline C2T4 & $79.17^{\text {abcd }}$ & $79.17^{\mathrm{abcd}}$ \\
\hline C2T5 & $66.67^{\text {bcd }}$ & $66.67^{\text {bcd }}$ \\
\hline C2T6 & $87.50^{\mathrm{abc}}$ & $87.50^{\mathrm{abc}}$ \\
\hline C2T7 & $75.00^{\text {abcd }}$ & $75.00^{\mathrm{abcd}}$ \\
\hline C2T8 & $58.33^{\text {cd }}$ & $58.33^{\mathrm{cd}}$ \\
\hline C2T9 & $70.83^{\mathrm{abcd}}$ & $70.83^{\mathrm{abcd}}$ \\
\hline C3T1 & $91.67^{\mathrm{ab}}$ & $91.67^{\mathrm{ab}}$ \\
\hline C3T2 & $91.67^{\mathrm{ab}}$ & $91.67^{\mathrm{ab}}$ \\
\hline C3T3 & $87.50^{\mathrm{abc}}$ & $87.50^{a b c}$ \\
\hline C3T4 & $75.00^{\mathrm{abcd}}$ & $75.00^{\mathrm{abcd}}$ \\
\hline C3T5 & $66.67^{\text {bcd }}$ & $66.67^{\text {bcd }}$ \\
\hline C3T6 & $79.17^{\text {abcd }}$ & $79.17^{\mathrm{abcd}}$ \\
\hline C3T7 & $91.67^{\mathrm{ab}}$ & $91.67^{\mathrm{ab}}$ \\
\hline C3T8 & $83.33^{\text {abcd }}$ & $83.33^{\mathrm{abcd}}$ \\
\hline C3T9 & $75.00^{\mathrm{abcd}}$ & $75.00^{\mathrm{abcd}}$ \\
\hline F Computed & $2.00^{*}$ & $2.00 *$ \\
\hline $\mathrm{CV}(\%)$ & 21.22 & 21.22 \\
\hline
\end{tabular}

treatment of rooting hormone (26). Table 4 showed that there was no significant difference in any of the treatments of IBA and BioGroe applied to Bignay cuttings. This conforms with the findings where IBA, NAA and their combination treatments were not significant in rooting azalea cuttings (27).

The interaction effect of cutting origin and various concentrations of hormones was observed to have a significant difference among each other (Table 5). This result coincides with the findings in rooting the stem cuttings of African Blackwood (Dalbergia melanoxylon Guill. \& Perr.) (28). It was revealed that the highest percent rooting was observed on the top cuttings applied with 500 ppm IBA (100\%). Comparison of means using DMRT showed that this was statistically the same with the middle cuttings applied with 500 ppm BioGroe (87.50\%). Economically, the result showed that the best combination of treatment to use in rooting bignay stem cuttings would be middle cuttings applied with 500 ppm BioGroe since it is cheaper than IBA.

\section{Number of Adventitious Roots}

The effect of cutting origin on the number of adventitious roots produced in the cuttings is not significant (Table 2). As shown in Table 3, the highest number of adventitious roots was recorded by top cuttings (1.93) while the least was observed in middle cuttings (1.74). This indicates that the numerical difference between the cutting origin means is not enough to create a significant difference among each other, hence they are treated statistically equal. This implies that the origin of cuttings does not influence the number of adventitious produced by the respective cuttings. The result was opposite to the findings of (29) where softwood cuttings significantly increase the number and length of adventitious roots of Tindalo cuttings.

Table 4 revealed that the greatest number of adventitious roots produced was exhibited by cuttings treated with $2000 \mathrm{ppm}$ IBA (2.56) followed by cuttings applied with 1000 ppm IBA (2.00) and the least was noted in control (1.44). This contradicts with a research finding (30) where root production of Holarrhena pubescens Wall. ex G. Don is a little more receptive to lower levels of IBA concentrations. Analysis of Variance revealed no significant difference among the different rooting hormone treatments (Table 2). It implies that the mean number of adventitious roots was statistically the same even when applied with different levels of IBA and BioGroe. This means that with or without the application of hormones such as IBA and BioGroe, the number of adventitious roots produced by the cuttings will still be the same. Bignay stem cuttings can produce roots even without the application of the rooting hormone. This conforms with the findings on rooting of Drimys brasiliensis Miers, Ficus elastica Roxb. ex Hornem and Albizia zygia (DC.) J. F. Macbr. respectively $(31,32,33)$. Their findings showed that the rooting hormone treatment tested by them did not influence the number of roots per cutting, percentage of rooted cuttings, percentage of cuttings with callus and length of the longest roots per cuttings.

\section{Length of Shoots}

The longest shoot $(12.48 \mathrm{~mm})$ was obtained by the bottom cuttings while the lowest $(8.71 \mathrm{~mm})$ was obtained by top cuttings (Table 3). Analysis of variance revealed that there is a significant difference among cutting origin means. This means that the length of shoots differs from each other. Further analysis using LSD in comparing the means of cutting origin showed that the longest shoot (12.48 $\mathrm{mm}$ ) was obtained by the bottom cuttings that were statistically the same with middle cuttings (10.96 $\mathrm{mm}$ ). Meanwhile, the shortest shoot obtained on top cuttings with a mean length of $8.71 \mathrm{~mm}$ was found to be statistically different from bottom cuttings (12.48 $\mathrm{mm})$.

Furthermore, in terms of the effect of the various concentrations of IBA and BioGroe to the length of shoots produced by the cuttings, data showed that there is no significant difference among the treatment means. The same findings were recorded on the stem cuttings of $A$. bunius as with that of the length of adventitious shoots of Swietenia macrophylla King, of which they were not significantly affected by the IBA treatments (34) but they differ on the significant effect of different doses of indole-3-butyric acid (IBA) on the shoot length and other vegetative growth performance of hardwood cuttings of Flordaguard peach (35).

The longest shoot was noted in cuttings applied with $2000 \mathrm{ppm}$ IBA $(14.75 \mathrm{~mm})$ followed by cuttings applied with $1000 \mathrm{ppm}$ IBA (12.52 mm) while the shortest was achieved by cuttings applied with 500 ppm IBA $(8.81 \mathrm{~mm})$. This implies that even if the 
mean length was numerically different from each other, they are still statistically the same as revealed by the Analysis of Variance.

Likewise, the interaction of Factor A and Factor $B$ as revealed by the Analysis of Variance shows no significant difference between each other. This implies that the different treatment combinations, when used in 'bignay', have a comparable result.

\section{Conclusion}

The study revealed that 'Bignay' stem cuttings are effectively rooted and survived using the three cutting origins. Further, rooting of $A$. bunius ('Bignay') cuttings does not necessarily need the application of growth hormones such as IBA and Biogroe since the cuttings produced roots and survived easily without the aid of these treatments. For the mass production of Bignay cloned seedlings, it is best to use any cutting origins severed from the test plants without exogenous auxin application. Findings of this study may be used as macro-clonal propagation protocol for 'bignay' to economically propagate and adequately supply the planting materials needed by wine producers in the upland communities in Quirino province.

\section{Acknowledgements}

The authors were very grateful to DOST - PCAARRD for funding the research project. Likewise, the authors would like to thank Irene D. Dimaangna, Liwa F. Mamaoag and Rodolfo Luis who provided technical help in completing the study. We would also like to acknowledge the administration of QSU, LGU's and DENR within the province, including PO's for the support extended to the research.

\section{Authors' contributions}

EV Benabise, JJ Quinan, JG Carig had contributed equally in this work.

\section{Conflict of interests}

Authors do not have any conflict of interest to declare.

\section{References}

1. Philippines. Department of Sciences and Technology. Philippine native trees-what to plant in different provinces [Internet]. Laguna: PCAARD; 2015 [cited 2019 Sept 9]. Available from: http://www.pcaard.dost.gov.ph

2. Tarriela FG. Why native trees. Manila Bulletin [Internet]. 2018 Feb 7 [cited 2019 Oct 15]. Available from: https://mb.com.ph/2018/02/07/why-native-trees/

3. Oliva, MTM. Philippine Native Trees. Green Convergence [Internet]. 2019 Oct. 23 [cited 2019 Nov 29]. Available from: http://greenconvergencephil.com/philippine-native-trees/

4. Cabansag MG. Species composition, diversity and richness in understanding threats on biodiversity conservation of Philippine native and indigenous species of trees. Int J Appl Environ Sci. [Internet]. 2016 [cited 2019 March 15];11(3):75972. Available

https://www.ripublication.com/ijaes16/ijaesv11n3_05.pdf

5. Philippines. Department of Environment and Natural Resources-Ecosystem Research and Development Bureau. Natural dyes [Internet]. RISE: DENR-ERDB; 1999 [cited 2019 Nov 29];11(1):6-8. Available from: http://erdb.denr.gov.ph/wpcontent/uploads/2015/05/r_v11n1.pdf
6. Hardinasinta G, Mursalim M, Muhidong J, Saledngke S Determination of some chemical compounds of bignay (Antidesma bunius) fruit juice. Int J Fruit Sci. [Internet]. 2020 [cited 2020 Jan 15];8(1-2):15-34. Available from: https://doi.org/ $10.1590 /$ fst. 27720

7. Belmi RM, Giron J, Tansengco ML. Antidesma bunius (Bignay) extract as an organic pesticide against Epilachna spp. J Asian Scie Res. [Internet]. 2014 [cited 2020 April 11];4(7):320-27. Available from: http://www.aessweb.com/journals/5003

8. Shekhawat MS, Manokari M. Impact of auxins on vegetative propagation through stem cuttings of Couroupita guianensis Aubl.: A conservation approach [internet]. 2016 [cited 2019 Oct 15]. Available from: https://doi.org/10.1155/2016/6587571

9. Bhuyan L, Sharma CL, Singh B, Sharma MB. Vegetative propagation of two important Garcinia sp. of Assam, NE India. J Med Plants Stud. [Internet]. 2017 [cited 2019 Aug 25]; 5(3): $\begin{array}{ll}\text { 273-77. Available } & \text { from } \\ \text { https://www.plantsjournal.com/archives/2017/vol5issue3/.pdf }\end{array}$

10. USA. University of Auburn. Overview of cutting propagation [Internet]. Alabama: Department of Forestry; 1997 [cited 2019 Oct 15]. Available from: http://www.rooting-hormone.com/hudson.html

11. Philippines. Clonal propagation of selected high-premium tree species [Internet]. Laguna: PCAARRD; 2007 [cited 2019 Nov 29]. Available from: http://www.pcaard.dost.gov.ph

12. Beyl CA, Trigiano RN. Introduction to plant propagation: plant propagation concepts and laboratory exercises [e-book]. $2^{\text {nd }}$ Edition. Boca Raton, Florida: CRC Press; 2015. [cited 2019 Sept 27]. Available from: https://doi.org/10.1201/b17340

13. Beyl CA, Burger DW, Cheng ZM. Plant growth substances used in propagation plant: propagation concepts and laboratory exercises [e-book]. $2^{\text {nd }}$ Edition. Boca Raton, Florida: CRC Press; 2015. [cited 2019 Nov. 19]. Available from: https://www.routledge.com>Beyl-Trigiano>book

14. Leakey RRB. Physiology of vegetative reproduction Encyclopedia of forest sciences [e-book]. San Diego: Academic Press; 2004 [cited 2019 Nov. 07]. Available from: https://doi.org/ 10.1016/B0-12-145160-7/00108-3

15. Mazzini-guedes RB, Nogueira MR, Ferraz MV, Bezerra AK, Pereira TS, Pivetta KFL. Rooting of Azalea cuttings (Rhododendron $x$ simsii Planch.) under indolebutyric acid and boron concentrations. Int. J. New Technol. and Res. 2017;3:15862.

16. Frick EM, Strader LC. Roles for IBA-derived auxin in plant development. J Exp Bot. [Internet]. 2018 [cited 2020 Feb. 25]; 69(2l):169-77. Available from: https://doi.org/10.1093/jxb/erx298

17. Pollisco MT. Rooting hormone and their practical application to macro-vegetative propagation by cuttings. Paper presented at National Plant Propagation Congress; Philippines; 2002 Sept. 3-5.

18. Philippines. Department of Science and Technology -Invention Development Division. Nano-encapsulated plant growth regulators [Internet]. DOST-IDD; 2019 [cited 2019 Nov 29]. Available from: https://techtrans.gov.ph/trademark/plantgrowth-regulator

19. Philippines. BIOGROE Technology: Paving the way for efficient fertilizer use and increased farmer's income. [Internet]. Laguna: PCAARRD Monitor; 2013 [cited 2020 Jan. 29]. Available from: https://biotech.uplb.edu.ph/images/stories/Biogroe $\% 20$ article.pdf

20. George EF. Plant propagation by tissue culture. $2^{\text {nd }}$ Edition. Exigatics Limited Publication, UK. 2003.

21. Tombesi S, Palliotti A, Poni S, Farinelli D. Influence of light and shoot development stage on leaf photosynthesis and carbohydrate status during the adventitious root formation in cuttings of Corylus avellana L. Front Plant Sci. [Internet]. 2015 [cited 2020 Jan. 15];6:1-13. Available from: https://doi.org/10.3389/fpls.2015.00973

22. Abidin N, Metali F. Effects of different types and concentrations of auxins on juvenile stem cuttings for propagation of potential medicinal Dillenia suffruticosa Martelli shrub. Res J Bot. [Internet]. 2015 [cited 2020 Mar. 17];10(3);73-87. Available https://doi.org/10.3923/rjb.2015.73.87

23. Patel HR, Patel MJ. Role of auxins on rooting of different types of cuttings in Fig. Int J Cur. Microbiol App Scie. [Internet]. 2018 [cited 2020 April 27];7:1317-22. Available from: https://doi.org/ 10.20546/ijcmas.2018.703.157

24. Castro C, Bonfil CC. Propagation of three Bursera species from cuttings. Bot Sci. [Internet]. 2013 [cited 2020 June 21];91(2): 217-24. Available from: https://doi.org/10.17129/botsci.416

25. Baul TK, Hossain MM, Mezbahuddin M, Mohiuddin M. Vegetative propagation of Litsea monopetala, a wild tropical 
medicinal plant: Effects of indole-3-butyric acid (IBA) on stem cuttings. J For Res. [Internet]. 2011 [cited 2020 May 13];22(3): 409-16. Available from: https://doi.org/10.1007/s11676-0110111-x

26. Kassahun BM, Mekonnen SA. Effect of cutting position and rooting hormone on propagation ability of Stevia (Stevia rebaudiana Bertoni). The Afr J Plant Sci Biotech. [Internet]. 2011 [cited 2020 Feb. 18];6:5-8. Available from http://www.globalsciencebooks.info/Online/GSB Online/images/2012/AJPSB 6(SI1)/AJPSB_6(SI1)5-80.pdf

27. Hou PC, Lin KH, Huang YJ, Wu CW, Chang YS. Evaluation of vegetation indices and plant growth regulator use and the rooting of Azalea cuttings. Hortic Bras. [Internet]. 2020 [cited 2020 Jan. 05];38:153-59. Available from: http://doi.org/10.1590/S0102-053620200207

28. Amri E, Lyaruu HVM, Nyomora AS, Kanyeka ZL. Vegetative propagation of African Blackwood (Dalbergia melanoxylon Guill. \& Perr.): effects of age of donor plant, IBA treatment and cutting position on rooting ability of stem cuttings. New For. [Internet]. 2010 [cited 2020 June. 09];39:183-94. Available from: https://doi.org/10.1007/s11056-009-9163-6

29. Kouakou KL, Dao JP, Kouassi KI, Beugré MM, Koné P, Zoro Bi IA. Propagation of Garcinia kola Heckel by stem and root cuttings. Silva Fenn. [Internet]. 2016 [cited 2020 April 16] 50(4):1588. Available from: https://doi.org/10.14214/sf.1588

30. Baul TK, Mezbahuddin M, Hossain MM, Mohiuddin M Vegetative propagation of Holarrhena pubescens, a wild tropical medicinal plant: Effects of indole-3-butyric acid (IBA) on stem cuttings. For Stud China. [Internet]. 2010 [cited 2020 July 14];12(4):228-35. Available from: https://doi.org/10.1007/s11632-010-0409-3

31. Zem L, Ribas K, Radomski M, Koehler H. Rooting of semihardwood stem cuttings from current year shoots of Drymis brasiliensis. Ciênc. Rural [Internet]. 2016 [cited 2020 Mar. 04] 46 (12):2129-34. Available from: https://doi.org/10.1590/0103$8478 \mathrm{cr} 20141486$

32. Li N, Tu PC, Lo KC, Chang YS. The induction of adventitious roots regeneration before transplanting rootless Ficus elastica heritage tree. Forests [Internet]. 2020 [cited 2020 Mar. 22]; 11(10):1057. Available from: https://doi.org/10.3390/f11101057

33. Egbe EA, Chuyong GB, Fonge AB, Tata BL, Tabot PT. The effects of different concentrations of indole-3-butyric acid (IBA) on leafy stem cuttings of four tropical timber species. Int J Hortic Flor. [Internet]. 2020 [cited 2020 Jul. 13];8(3):001-07. Available from: https://doi.org/10.46882/IJHF/1117

34. Azad S, Matin A. 2015. Effect of indole-3-butyric acid on clonal propagation of Swietenia macrophylla through branch cutting. J Bot. [Internet]. 2015 [cited 2020 Feb. 08]; Available from: https://doi.org/10.1155/2015/249308

35. Kaur S. Evaluation of different doses of indole-3-butyric acid (IBA) on the rooting, survival and vegetative growth performance of hardwood cuttings of Flordaguard peach (Prunus persica (L.) Bats(ch). J Appl Nat Sci. [Internet]. 2017 [cited 2020 June 26];9(1):173-180. Available from: https://doi.org/10.31018/ jans.v9i1.1167

\section{Additional information}

Peer review information: Plant Science Today thanks Sectional Editor and the other anonymous reviewers for their contribution to the peer review of this work.

Reprints and permissions information is available at https://horizonepublishing.com/journals/index.php/PST/open_access_policy Publisher's Note: Horizon e-Publishing Group remains neutral with regard to jurisdictional claims in published maps and institutional affiliations.

To cite this article: Benabise E V, Quinan J J, Carig J G. Response of 'Bignay' [Antidesma bunius (Linn.) Spreng] to cutting origins, IBA and BioGroe treatments. Plant Science Today. 2021;8(3):596-603. https://doi.org/10.14719/ pst.2021.8.3.1063

Plant Science Today, published by Horizon e-Publishing Group, is covered by Scopus, Web of Science, BIOSIS Previews, Clarivate Analytics, etc. Full list at https://horizonepublishing.com/journals/index.php/PST/indexing_abstracting 